\section{Genetic Diversity and Heritability of In Vitro Leaf Regeneration Ability in Malus Species}

\author{
Yi Tan, Baisha Li, Yi Wang, Ting Wu, Zhenhai Han, \\ and Xinzhong Zhang ${ }^{1}$ \\ Institute for Horticultural Plants, China Agricultural University, No. 2 \\ Yuanmingyuan West Road, Haidian District, Beijing 100193, Peoples \\ Republic of China
}

Additional index words. apple, inheritance, phenological stage, regeneration

\begin{abstract}
Agrobacterium-mediated genetic transformation is commonly used in dicotyledon plants such as apples. The regeneration ability of the recipient is an important factor in transformation efficiency. Here, the variations in bud regeneration rate (BRR) and the number of adventitious buds (NAB) formed per explant in Malus germplasm accessions with phenological stage were estimated. Both BRR and NAB of explants at the dormancy broken and spring sprouting stages were significantly higher than those at the autumn sprouting stage. The genetic diversity and inheritance of BRR and NAB were evaluated using 153 Malus germplasm accessions and 78 hybrid trees of Jonathan $\times$ Golden Delicious. Malus sieversii 31, Liberty, and Smoothee exhibited significantly high BRR $(98.33 \%, 98.33 \%$, and $93.33 \%$, respectively) and a large NAB without vitrification. BRR and NAB linearly correlated with each other but not with callus formation rate. The broad sense heritability of the regeneration rate was $92.16 \%$. The three Malus accessions that had high regeneration ability, and some of their sexual descendants, might be outstanding genetic resources for future genetic transformation.
\end{abstract}

Agrobacterium-mediated genetic transformation is an efficient and preferred system not only for genetic improvement but also for the study of candidate genes in a majority of nonmodel dicotyledons (Flachowsky et al., 2012; Metwali et al., 2016; Requesens et al., 2014; Zhang et al., 2014). A high rate of in vitro regeneration is the first prerequisite for successful transformation, but many woody perennials such as Malus species are rather recalcitrant to regeneration.

The regeneration ability of dicots varies substantially across taxa and genotypes. For example, BRRs were up to $87.7 \%$ in European pear (Pyrus communis L.) cultivars Williams, Dar Gazi, and Conference, whereas no buds regenerated in cultivars $\mathrm{Ya} \mathrm{Li}$, Old Home, and Fondante de Charneuse (Abdollahi et al., 2006; Bell et al., 2012). The leaf regeneration percentage was as low as $12.8 \%$ in the peach (Prunus persica L.) genotype 842 Standard and was as high as $71.7 \%$ in Nemaguard, a rootstock of peach (Gentile et al., 2002; Zhou et al., 2010). Among seven commercial strawberry (Fragaria $\times$ ananassa

Received for publication 18 July 2017. Accepted for publication 31 Aug. 2017.

We thank the earmarked fund for China Agriculture Research System (CARS-27), the Key Laboratory of Biology and Genetic Improvement of Horticultural Crops (Nutrition and Physiology), Ministry of Agriculture, People's Republic of China, and grants from the Beijing Municipal Education Commission (CEFF-PXM2017_ 014207_000043).

${ }^{1}$ Corresponding author. E-mail: zhangxinzhong999@ 126.com.
Duch.) cultivars, the regeneration rates of leaf discs ranged from $0 \%$ to $100 \%$, and Calypso had the highest regeneration rate of $100 \%$ (Passey et al., 2003). In Malus species, leaves of 28 cultivars or stocks had regeneration rates that ranged between $5 \%$ and $100 \%$ (Sun et al., 2000). An apple genotype, GL-3, was screened out from 100 in vitro seedling clones of Royal Gala with both 100\% regeneration capacity and the highest number of regenerated buds per explant (Dai et al., 2013).

Many factors affect regeneration capacity, including age of leaf and ontogenetic phase of donor plants. Regeneration capacity in explants can also vary by organ. In Malus sp., the age of leaves is a major factor in regeneration ability. Young expanding leaves were the most suitable for regeneration (De Bondt et al., 1996; Famiani et al., 1994; Fasolo et al., 1989; Welander, 1988). With young leaves as explants, the regeneration rate of peach was $\approx 64.8 \%$ (Soliman, 2013). Among the ontogenetic phases of the donor plant Prunus serotina, the best regeneration (91.4\%) was obtained using materials from juvenile plants, whereas the regeneration rates of two reproductively mature genotypes varied from $0 \%$ to $41.7 \%$ (Liu and Pijut, 2008). Regeneration ability also varies significantly among organs of donor plants. No transformants of La France pear were obtained from in vitro leaves because of its low regeneration frequency, but its transformation efficiency was up to $4.8 \%$ using axillary shoot meristems as explants (Matsuda et al., 2005). A high regeneration rate has been obtained from calluses that originated from in vitro shoots in some apple cultivars and rootstocks (Jork9, M26, Gala, and McIntosh) (Caboni et al., 2000). Cotyledons are sometimes used as potential explants for genetic transformation (Ellul et al., 2003; Sujatha et al., 2012). In Asian pear (Pyrus pyrifolia Nakai) cultivar Imamuraaki, of the 1014 inoculated cotyledons, three transformants with VlmybA1-2 gene were obtained from 58 regenerated shoots (Nakajima et al., 2013). The highest regeneration rates of $87.5 \%$ were obtained using proximal cotyledons as explants derived from seedlings in vitro in Malus micromalus (Dai et al., 2014). However, the disadvantage of using cotyledons in transgenic breeding of perennial fruit crops is the variability of agronomic traits in seedling populations.

Leaflets collected from shoots grown in vitro are more suitable for regeneration because the organogenetic apple somatic tissue is influenced by the age of the explants (James et al., 1988; Magyar-Tábori et al., 2010). By using leaflets from in vitro shoots as explants, transgenic lines have been successfully obtained in many apple cultivars or rootstocks (Bacha et al., 2012; Holefors et al., 2000; Requesens et al., 2014). GL-3, a progeny from open-pollinated Royal Gala with high regeneration capacity, has been used often in recent years for apple transformation using leaves from in vitro shoots (Dai et al., 2013; Wang et al., 2017). Another important reason for using leaves from in vitro shoots as source of explants for regeneration is the excellent uniformity between individuals and the reproducibility between experiments (Bulley and James, 2004).

In this study, to determine the differences in leaf regeneration capacity among the diverse genetic resource of Malus and to screen for elite easy-to-regenerate genotypes, the regeneration ability of 153 accessions of Malus genetic resources and 78 hybrid seedlings were evaluated and the inheritance of the BRR was analyzed.

\section{Materials and Methods}

Plant materials. To determine the appropriate sampling season for leaf regeneration, explants were collected during February to September of 2013 from 10 Malus germplasm accessions at three phenological stages: dormancy broken, spring sprouting (late April), and autumn sprouting (early September). To collect dormancy-broken explants, 1-year-old branches were cut in February (dormancy broken but before budbreak) and were hydroponically cultured for $20 \mathrm{~d}$ under a $16 / 8 \mathrm{light} /$ dark cycle at $25^{\circ} \mathrm{C}$ with $70 \%$ relative humidity. All explants were sampled from newly expanded young leaves (Fig. 1A).

One hundred and fifty-three Malus germplasm accessions were used for the assessment of genetic diversity in regeneration capacity, including 11 Chinese domestic cultivars, 96 commercial cultivars, 10 Malus sieversii accessions, 10 rootstocks, and 26 accessions of wild species (Supplemental Table 1). For the analysis of the inheritance 
of leaf regeneration ability, seventy-eight 11 year-old hybrid trees (Jonathan $\times$ Golden Delicious) were tested. For each germplasm accession and hybrid, dormancy-broken 1-year-old branches were cut before budbreak. After hydroponic culture as mentioned previously, newly unfolded young leaves of shoots were collected and used as explants. The experiments were carried out in three replicates, and more than 20 leaflets were used in each replicate.

Regeneration stage. Leaf explants were surface sterilized in $75 \%(\mathrm{v} / \mathrm{v})$ ethanol for $30 \mathrm{~s}, 0.1 \% \mathrm{HgCl}_{2}(\mathrm{w} / \mathrm{v})$ for $5-8 \mathrm{~min}$, and rinsed three times with sterile distilled water. The leaf blade was cut transversely into two sections (Fig. 1B) and cultured on the regeneration medium (MS $+4 \mathrm{mg} \cdot \mathrm{L}^{-1} \mathrm{TDZ}+$ $0.5 \mathrm{mg} \cdot \mathrm{L}^{-1} \mathrm{NAA}$ ) in the dark at 23 to $26{ }^{\circ} \mathrm{C}$ for $14 \mathrm{~d}$ then moved to a $16 / 8$ light/dark cycle (light intensity $1500 \mathrm{Lx}$ ). Then, the BRR (number of explants with adventitious buds/ total number of explants), the number of regenerated adventitious buds per explant (NAB/number of explants forming adventitious buds), and the callus formation rate (number of explants forming calluses/total number of explants) were calculated every $7 \mathrm{~d}$. The regenerated buds were finally transferred to the growth medium (MS +0.5 $\mathrm{mg} \cdot \mathrm{L}^{-1} 6-\mathrm{BA}+0.5 \mathrm{mg} \cdot \mathrm{L}^{-1} \mathrm{IBA}$ ) (Fig. 1C).

The BRR and the number of regenerated adventitious buds per explant were classified into four levels based on the following criteria:

Low: $0 \% \leq \mathrm{BRR}<20 \%$,

Relatively low: $20 \% \leq$ BRR $<50 \%$,

Relatively high: $50 \% \leq$ BRR $<90 \%$,

High: $B R R \geq 90 \%$;

None: $\mathrm{NAB}=0$,

Moderate: $0<\mathrm{NAB}<3$,

Relatively high: $3 \leq \mathrm{NAB}<9$,

High: NAB $\geq 9$.

Data analysis. Statistical significance was determined by $F$-tests and Duncan's multiplerange tests (Duncan, 1955). Pairwise Pearson correlation coefficients were calculated among the BRR, NAB, and callus formation rate. The heritability of BRR was estimated using the data from the 78 hybrid trees. Theoretically, the phenotypic value can be determined by the genotype and environment. Here, the phenotypic variance $(S)$ was calculated as the hybrid population total variance. The environmental variance $\left(S_{\mathrm{e}}\right)$ was computed by averaging the variances of each individual among the replicates. The genetic variance $\left(S_{\mathrm{g}}\right)$ was then estimated by subtracting $S_{\mathrm{e}}$ from $S$, and the heritability was expressed as $S_{\mathrm{g}} / S$.

\section{Results}

Leaf regeneration ability. The $\mathrm{BRR}$ and NAB varied significantly among both Malus accessions and phenological stages (Supplemental Table 2). Leaf explants collected from autumn sprouts exhibited both the lowest BRR and the lowest NAB owing to serious tissue browning (Fig. 2; Tables 1 and 2). The BRR and NAB were higher in dormancy-broken explants in some germplasm accessions such as Ralls Janet and Golden Delicious. In some germplasm accessions, e.g., M9 and Baleng $\mathrm{Crab}$, the BRR of spring sprouts were significantly higher (Tables 1 and 2). Therefore, explants from dormancy broken to spring sprouting stage were better for leaf regeneration.

Evaluation of the regeneration ability of Malus germplasm accessions. Leaves of 153

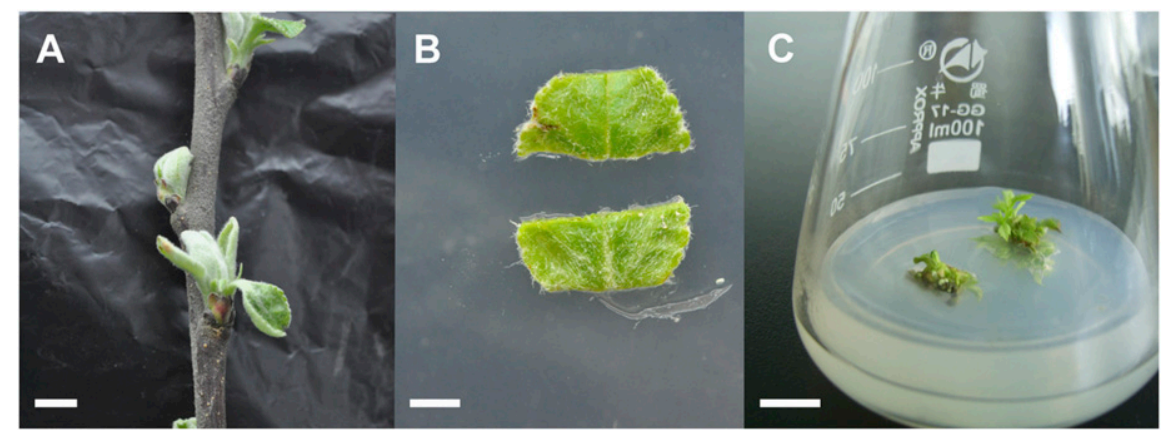

Fig. 1. (A) Newly expanded young leaves on 1-year-old branch $(\mathrm{bar}=1 \mathrm{~cm})$. (B) Two sections of leaf blade cultured on the regeneration medium (MS $\left.+4 \mathrm{mg} \cdot \mathrm{L}^{-1} \mathrm{TDZ}+0.5 \mathrm{mg} \cdot \mathrm{L}^{-1} \mathrm{NAA}\right)(\mathrm{bar}=2 \mathrm{~mm}) .(\mathrm{C})$ Regenerated adventitious buds cultured on the growth medium (MS $\left.+0.5 \mathrm{mg} \cdot \mathrm{L}^{-1} 6-\mathrm{BA}+0.5 \mathrm{mg} \cdot \mathrm{L}^{-1} \mathrm{IBA}\right)$ $($ bar $=1 \mathrm{~cm})$.

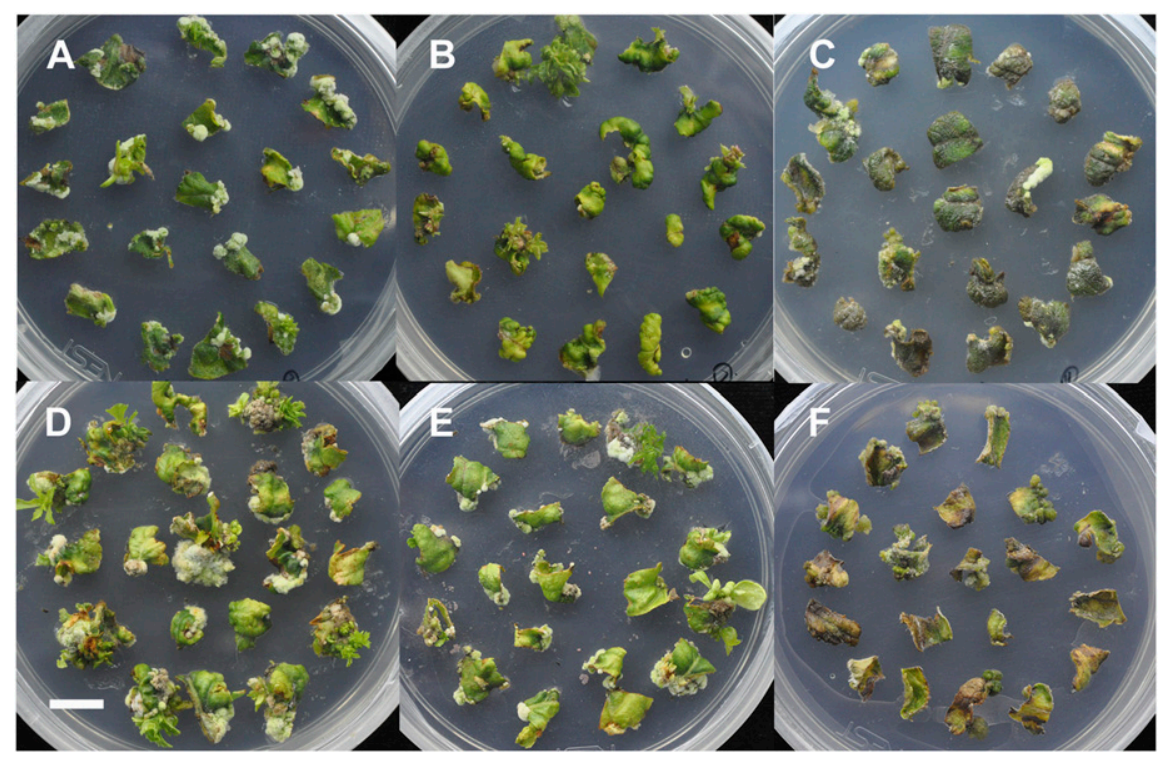

Fig. 2. Tissue browning and adventitious bud regeneration of the leaf explants collected from $(\mathbf{A}, \mathbf{D})$ dormancy-broken branches, $(\mathbf{B}, \mathbf{E})$ spring sprouts, and $(\mathbf{C}$ and $\mathbf{F})$ autumn sprouts. The explants in (A-C) were collected from the branches of Royal Gala (Malus domestica Borkh.), whereas the explants in (D-F) were from Baleng Crab (Malus robusta (Carr.) Rehd) $(\mathrm{bar}=1 \mathrm{~cm})$.

Table 1. Bud regeneration rates varied with phenological stages in 10 Malus genetic resource accessions.

\begin{tabular}{|c|c|c|c|}
\hline \multirow[b]{2}{*}{ Malus accessions ${ }^{2}$} & \multicolumn{3}{|c|}{ Bud regeneration rate $(\%)^{\mathrm{y}}$} \\
\hline & Dormancy broken & Spring sprouting & Autumn sprouting \\
\hline Royal Gala (M. domestica Borkh.) & $38.33 \pm 12.58 \mathrm{a}$ & $21.67 \pm 5.77 \mathrm{ab}$ & $13.33 \pm 7.64 \mathrm{~b}$ \\
\hline Ralls Janet (M. domestica Borkh.) & $21.67 \pm 10.41 \mathrm{a}$ & $0 \pm 0 \mathrm{~b}$ & $0 \pm 0 \mathrm{~b}$ \\
\hline Golden Delicious ( $M$. domestica Borkh.) & $13.33 \pm 5.77 \mathrm{a}$ & $0 \pm 0 \mathrm{~b}$ & $0 \pm 0 \mathrm{~b}$ \\
\hline M9 (M. pumila Mill.) & $8.33 \pm 5.77 b$ & $23.33 \pm 2.89 \mathrm{a}$ & $3.33 \pm 5.77 \mathrm{~b}$ \\
\hline Baleng Crab (M. robusta (Carr.) Rehd) & $6.67 \pm 2.89 \mathrm{~b}$ & $40.00 \pm 13.23 \mathrm{a}$ & $0 \pm 0 \mathrm{~b}$ \\
\hline M. xiaojinensis (M. xiaojinensis Cheng et Jiang) & $5.00 \pm 0 \mathrm{a}$ & $6.67 \pm 5.77 \mathrm{a}$ & $0 \pm 0 \mathrm{a}$ \\
\hline Jonagold ( $M$. domestica Borkh.) & $0 \pm 0$ & $0 \pm 0$ & $0 \pm 0$ \\
\hline Yama Fuji 2 (M. domestica Borkh.) & $0 \pm 0$ & $0 \pm 0$ & $0 \pm 0$ \\
\hline MM106 (M. pumila Mill.) & $0 \pm 0$ & $0 \pm 0$ & $0 \pm 0$ \\
\hline M. baccata 2 (M. baccata (L.) Borkh.) & $0 \pm 0$ & $0 \pm 0$ & $0 \pm 0$ \\
\hline
\end{tabular}

${ }^{\mathrm{z}}$ For each Malus accession, means in different phenological stages were studied with Duncan's multiplerange test. The same letter indicates no significant difference $(P<0.05)$.

${ }^{\mathrm{y}}$ Mean \pm SD. 
Malus germplasm accessions were collected at the dormancy-broken stage to evaluate regeneration ability. Significant variations in the BRR $\left(F=42.63, F_{0.05}=1.21, F_{0.01}=\right.$ $1.31)$ and $\mathrm{NAB}\left(F=42.95, F_{0.05}=1.21, F_{0.01}=\right.$ 1.31) were detected among the germplasm accessions (Supplemental Table 3).

The frequency distribution of regeneration rates of the 153 Malus germplasm accessions is shown in Fig. 3A. Ninety of $96(93.75 \%)$ commercial cultivars, eight of $10(80.00 \%)$ Malus sieversii genotypes, and 25 of $26(96.15 \%)$ genotypes from wild species, as well all Chinese domestic cultivars and rootstocks, had low or relatively low regeneration rates. The average regeneration rates of $M$. sieversii 31, Liberty, and Smoothee were $98.33 \%, 98.33 \%$, and $93.33 \%$, respectively (Fig. 4; Supplemental Table 1).

As shown in Fig. 3B, 10 of $11(90.91 \%)$ Chinese domestic cultivars, 90 of $96(93.75 \%)$ commercial cultivars, 8 of $10(80.00 \%)$ M. sieversii genotypes, 24 of $26(92.31 \%)$ wild species genotypes, and all 10 of the 10 $(100.00 \%)$ rootstocks exhibited none or a moderate number of regenerated buds per explant. However, two $M$. sieversii genotypes (M. sieversii 31 and $M$. sieversii 9 ) and five Malus $\times$ domestica cultivars (Liberty, Smoothee, Meile, Golden B, and Kitanosach) regenerated more than nine adventitious buds per leaflet on average (Supplemental Table 1).

Taken together, of the 153 accessions, $M$. sieversii 31, Liberty, and Smoothee were the best materials for regeneration because of their high regeneration rates $(>93.33 \%)$ and large NAB formed with no vitrification in the regenerated buds (Fig. 4).

Correlation analysis of different regeneration indices. Adventitious buds were induced in explants of 60 of the 153 germplasm accessions. Using these 60 accessions, correlation coefficients among the BRR, NAB, and callus formation rate were estimated. The BRR and NAB were positively correlated with each other $(P<0.0001)$ (Fig. 5), but no significant correlation was found between either BRR and callus formation rate $(P>0.05)$ or NAB and callus formation rate $(P>0.05)$.

Inheritance of regeneration ability. The BRR of Jonathan and Golden Delicious were $0 \%$ and $13.33 \%$, respectively (Supplemental Table 1), but both the $\operatorname{BRR}\left(F=11.63, F_{0.05}=\right.$ $\left.1.35, F_{0.01}=1.52\right)$ and $\mathrm{NAB}\left(F=11.98, F_{0.05}=\right.$ $\left.1.35, F_{0.01}=1.52\right)$ were significantly segregated among the 78 hybrids of Jonathan $\times$ Golden Delicious (Supplemental Table 4). The BRR of the hybrids ranged from $0 \%$ to $46.67 \%$; the BRR of $73(93.59 \%)$ hybrids was low, and the BRR of five (6.41\%) hybrids were relatively low (Fig. 6A; Supplemental Table 5). The NAB of all 78 hybrids were low or moderate (Fig. 6B). The ratio of genetic variance vs. total phenotypic variance was 0.9216 , indicating a very high broad sense heritability of the regeneration rate $(92.16 \%)$ (Table 3$)$.

\section{Discussion}

Leaf regeneration capacity was stronger from dormancy broken to the active spring
Table 2. The number of regenerated adventitious buds per explant varied with phenological stages in 10 Malus genetic resource accessions.

\begin{tabular}{|c|c|c|c|}
\hline \multirow[b]{2}{*}{ Malus accessions ${ }^{2}$} & \multicolumn{3}{|c|}{ No. of regenerated adventitious buds per explant ${ }^{y}$} \\
\hline & Dormancy broken & Spring sprouting & Autumn sprouting \\
\hline Royal Gala (M. domestica Borkh.) & $2.33 \pm 0.31 \mathrm{a}$ & $2.31 \pm 0.30 \mathrm{a}$ & $1.44 \pm 0.51 \mathrm{~b}$ \\
\hline Ralls Janet (M. domestica Borkh.) & $1.69 \pm 0.30 \mathrm{a}$ & $0 \pm 0 \mathrm{~b}$ & $0 \pm 0 \mathrm{~b}$ \\
\hline Golden Delicious (M. domestica Borkh.) & $1.58 \pm 0.52 \mathrm{a}$ & $0 \pm 0 \mathrm{~b}$ & $0 \pm 0 \mathrm{~b}$ \\
\hline M9 (M. pumila Mill.) & $2.22 \pm 0.69 \mathrm{a}$ & $3.57 \pm 1.16 \mathrm{a}$ & $0.33 \pm 0.58 \mathrm{~b}$ \\
\hline Baleng Crab (M. robusta (Carr.) Rehd) & $2.00 \pm 1.00 \mathrm{a}$ & $1.24 \pm 0.15 \mathrm{a}$ & $0 \pm 0 \mathrm{~b}$ \\
\hline M. xiaojinensis (M. xiaojinensis Cheng et Jiang) & $1.33 \pm 0.58 \mathrm{a}$ & $2.00 \pm 1.80 \mathrm{a}$ & $0 \pm 0 \mathrm{a}$ \\
\hline Jonagold (M. domestica Borkh.) & $0 \pm 0$ & $0 \pm 0$ & $0 \pm 0$ \\
\hline Yama Fuji 2 (M. domestica Borkh.) & $0 \pm 0$ & $0 \pm 0$ & $0 \pm 0$ \\
\hline MM106 (M. pumila Mill.) & $0 \pm 0$ & $0 \pm 0$ & $0 \pm 0$ \\
\hline M. baccata 2 (M. baccata (L.) Borkh.) & $0 \pm 0$ & $0 \pm 0$ & $0 \pm 0$ \\
\hline
\end{tabular}

$\overline{{ }^{\mathrm{z}} \text { For each Malus accession, means in different phenological stages were studied with Duncan's multiple- }}$ range test. The same letter indicates no significant difference $(P<0.05)$.

${ }^{\mathrm{y}}$ Mean $\pm \mathrm{SD}$.
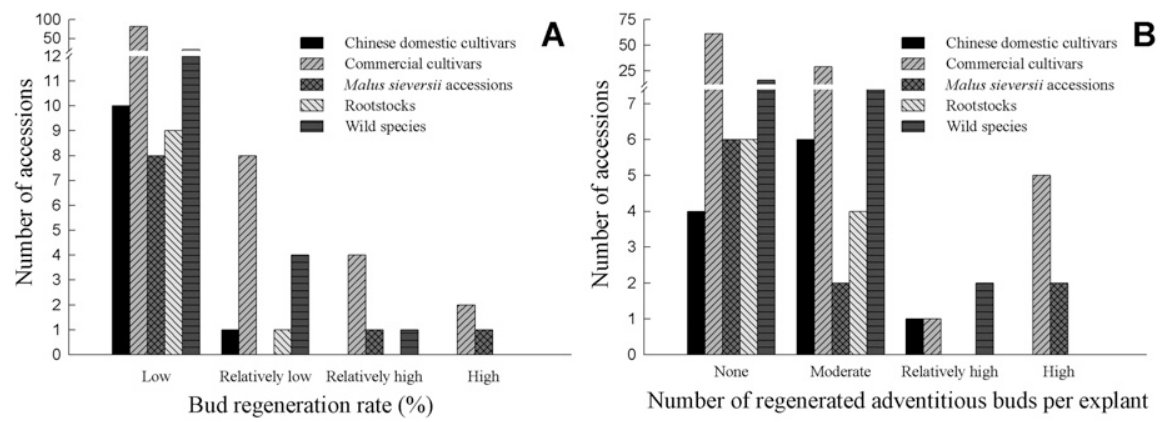

Fig. 3. (A) Frequency distribution of the bud regeneration rates (BRRs) of 153 Malus germplasm accessions. The BRR was classified into four levels: Low $(0 \% \leq$ BRR $<20 \%)$, Relatively low $(20 \% \leq$ BRR $<50 \%)$, Relatively high $(50 \% \leq \mathrm{BRR}<90 \%$ ), and High (BRR $\geq 90 \%$ ). (B) Frequency distribution of the numbers of regenerated adventitious buds per explant of 153 Malus germplasm accessions. The number of regenerated adventitious buds per explant $(\mathrm{NAB})$ was classified into four levels: None $(\mathrm{NAB}=0)$, Moderate $(0<\mathrm{NAB}<3)$, Relatively high $(3 \leq \mathrm{NAB}<9)$, and High $(\mathrm{NAB} \geq 9)$.

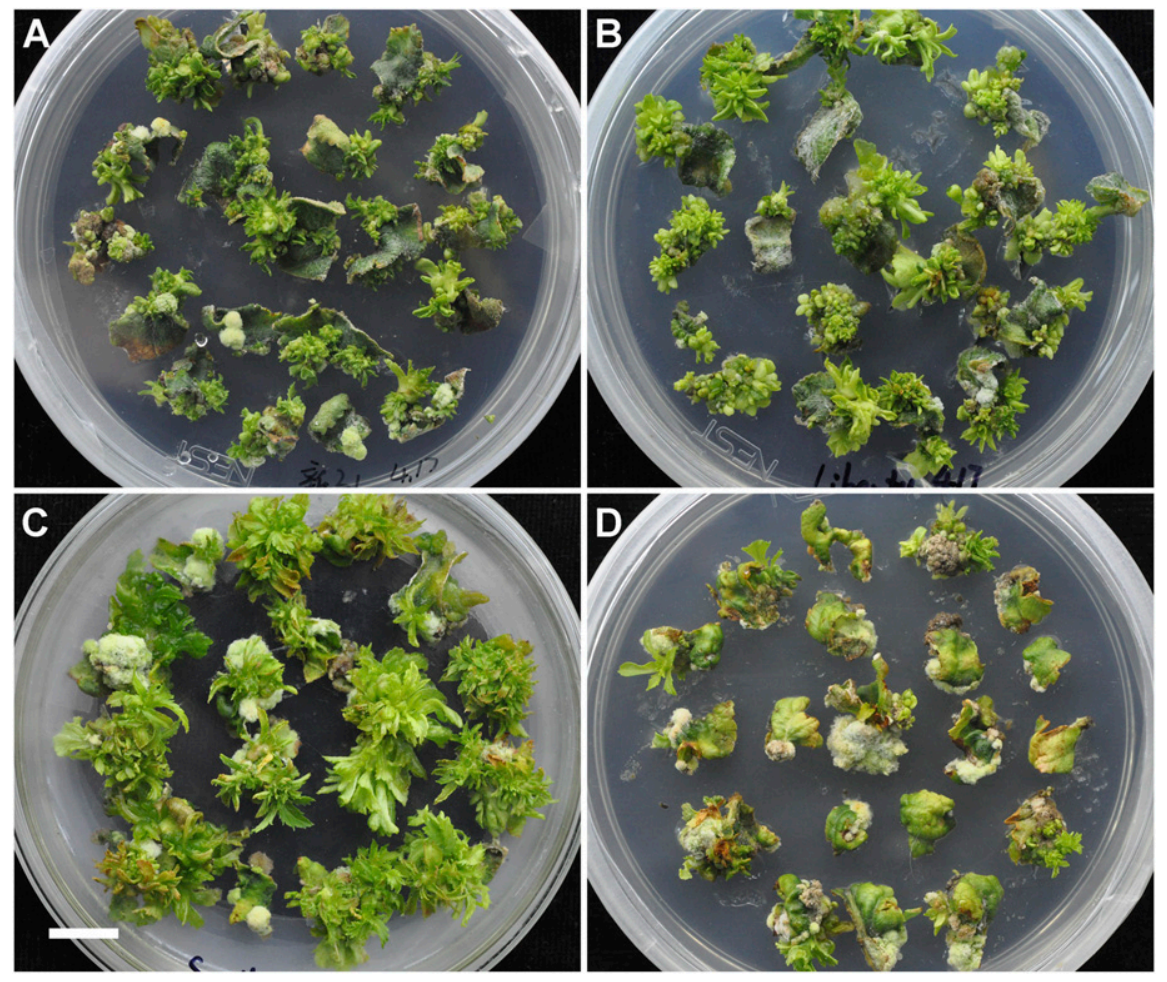

Fig. 4. The regeneration of leaf explants of (A) Malus sieversii 31 (M. sieversii (Ledeb.) Roem.), (B) Liberty (Malus domestica Borkh.), (C) Smoothee (M. domestica Borkh.), and (D) Royal Gala (M. domestica Borkh.) collected on dormancy-broken branches. Almost every explant of (A) M. sieversii 31, (B) Liberty, and (C) Smoothee produced numerous adventitious buds without vitrification. In comparison, their regeneration rates and numbers of adventitious buds per explant were far more than those of the commonly used cultivar $(\mathbf{D})$ Royal Gala $(\mathrm{bar}=1 \mathrm{~cm})$. 
shoot growth after budburst than during autumn sprouting. Explant browning during the initial stage is a common problem in in vitro regeneration. The browning leaf segments were significantly heavier in explants collected in autumn sprouts than in dormancy broken and spring sprouts. This was consistent with the decreased browning that occurred when explants were collected in spring or summer (Modgil et al., 1999; Wang et al., 1994). Wounds on explants caused an increase in polyphenol oxidase and peroxidase, which could oxidize phenolic compounds to highly toxic quinone compounds in explants and result in explant browning (Leng et al., 2009; Pan and van Staden, 1998). When the explants were collected in autumn, abundant highly toxic quinone compounds were produced because of the high content of phenolic compounds and resulted

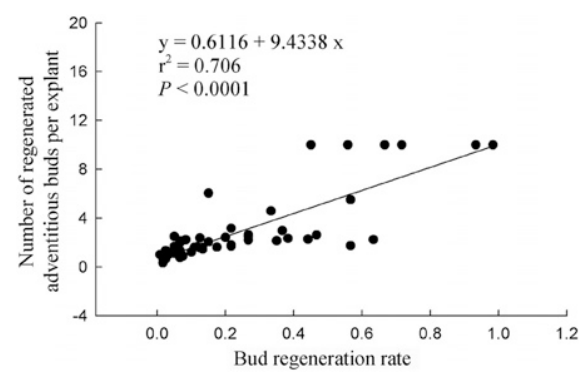

Fig. 5. Correlation between bud regeneration rate and number of regenerated adventitious buds per explant using 60 Malus germplasm accessions with nonzero regeneration rates.
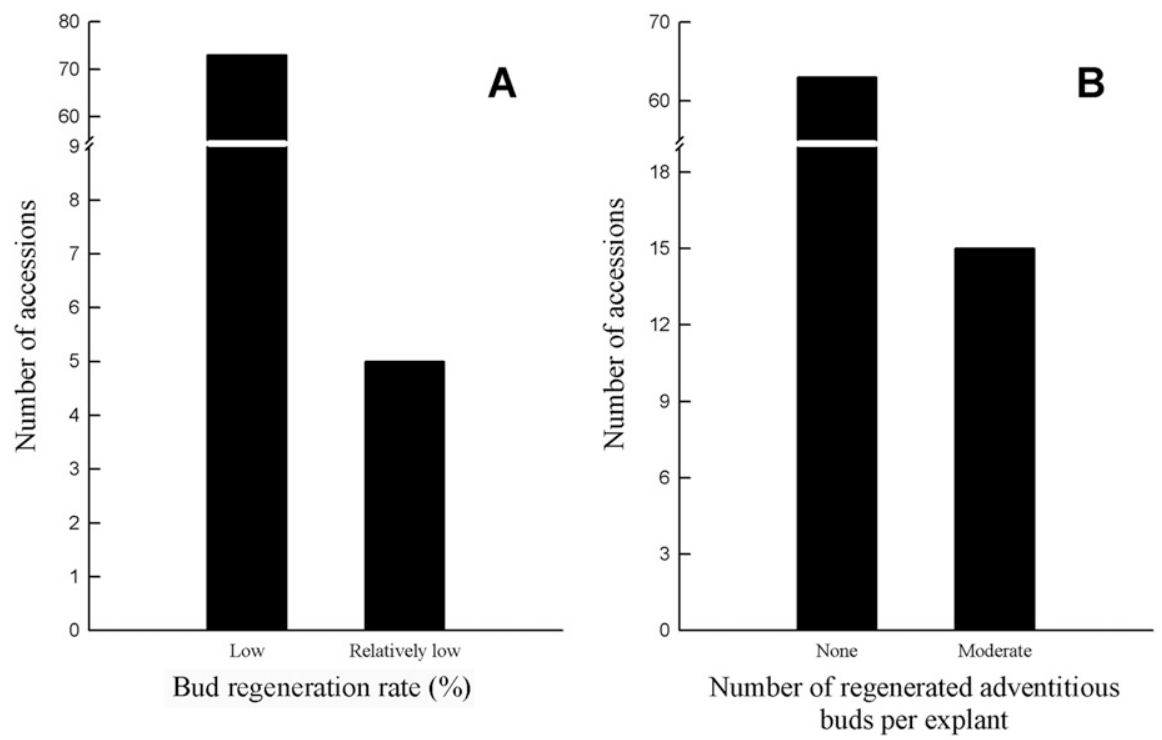

Fig. 6. (A) Frequency distribution of the bud regeneration rates of 78 hybrids from Jonathan $\times$ Golden Delicious. The bud regeneration rate (BRR) was classified into two levels: Low $(0 \% \leq B R R<20 \%)$ and Relatively low $(20 \% \leq \mathrm{BRR}<50 \%)$. (B) Frequency distribution of the numbers of regenerated adventitious buds per explant of the 78 hybrids. The number of regenerated adventitious buds per explant $(\mathrm{NAB})$ was classified into two levels: None $(\mathrm{NAB}=0)$ and Moderate $(0<\mathrm{NAB}<3)$.

Table 3. Heritability of the bud regeneration rate in the hybrids of Jonathan $\times$ Golden Delicious.

\begin{tabular}{lccc}
\hline Phenotypic variance $(S)$ & Genetic variance $\left(S_{\mathrm{g}}\right)$ & Environmental variance $\left(S_{\mathrm{e}}\right)$ & Heritability $(\%)$ \\
\hline 0.0297 & 0.0273 & 0.0023 & 92.16
\end{tabular}

several genes such as IRT2, Rirol, and rolC (Cong et al., 2006; Qu et al., 2005; Wang et al., 2007) (Table 1). The regeneration rate of cotyledons from a seedling of Baleng Crab was $87.5 \%$ (Dai et al., 2014).

Adventitious bud formation could be induced directly or indirectly from leaves. Direct adventitious bud formations occurred without intermediate proliferation of the callus phase, and thus, the whole regeneration process was completed soon as 23 weeks from explanting. However, indirect organogenesis that developed slowly via a callus phase occurred within 12 weeks (Gahan and George, 2008; James et al., 1988; Pawlicki and Welander, 1994). In some cultivars, such as Jonagold, New Jonagold, and Fuji, the indirect BRRs may not be low (De Bondt et al., 1996; Saito and Suzuki, 1999; Zhang et al., 1997). In this paper, the BRR of Jonagold was zero, but the callus formation rate of Jonagold was $100 \%$, which implied great potential for callus-intermediated adventitious bud regeneration. In this experiment, we did not perform histological analysis; therefore, could not determine the exact origin of the adventitious buds, but regeneration occurred since the fourth week and finally examined at the 10th week after induction (Supplemental Tables 1 and 5), so the adventitious buds might have regenerated directly from the leaf tissue. Therefore, the correlation coefficient between the BRR and NAB was highly significant, but no significant correlation was detected between callus formation and the BRR.

\section{Literature Cited}

Abdollahi, H., R. Muleo, and E. Rugini. 2006. Optimisation of regeneration and maintenance of morphogenic callus in pear (Pyrus communis L.) by simple and double regeneration techniques. Sci. Hort. 108:352-358.

Aldwinckle, H. and M. Malnoy. 2009. Plant regeneration and transformation in the Rosaceae. Transgenic Plant J. 3(Special Issue 1):1-39.

Bacha, N.M.A., A.A. Kader, H.J. Jacobsen, and F. Hassan. 2012. Production of transgenic apple (Malus domestica Borkh.) for improvement of fungal resistance. Acta Hort. 961:195-203.

Bell, R.L., R. Scorza, and D. Lomberk. 2012. Adventitious shoot regeneration of pear (Pyrus spp.) genotypes. Plant Cell Tissue Organ Cult. 108:229-236.

Biedermann, I.E.G. 1987. Factors affecting establishment and development of Magnolia hybrids in vitro. Acta Hort. 212:625-629.

Bulley, S.M.W. and D.J. James. 2004. Regeneration and genetic transformation of apple (Malus spp.), p. 199-214. In: I.S. Curtis (ed.). Transgenic crops of the world: Essential protocols. Springer, Dordrecht, Zuid-Holland.

Caboni, E., P. Lauri, and S. D'Angeli. 2000. In vitro plant regeneration from callus of shoot apices in apple shoot culture. Plant Cell Rep. 19:755-760.

Cong, Y., S.H. Wang, H.X. Wang, Q.H. Yao, and Z. Zhang. 2006. Transformation of $\mathrm{rolC}$ gene to Malus robusta by SAAT. J. Fruit Sci. 23:659663.

Dai, H.Y., W.R. Li, G.F. Han, Y. Yang, Y. Ma, H. Li, and Z.H. Zhang. 2013. Development of a seedling clone with high regeneration 
capacity and susceptibility to Agrobacterium in apple. Sci. Hort. 164:202-208.

Dai, H.Y., W.R. Li, W.J. Mao, L. Zhang, G.F. Han, K. Zhao, Y.X. Liu, and Z.H. Zhang. 2014. Development of an efficient regeneration and Agrobacterium-mediated transformation system in crab apple (Malus micromalus) using cotyledons as explants. In Vitro Cell. Dev. Biol. Plant 50:1-8.

Dare, A.P., S. Tomes, M. Jones, T.K. McGhie, D.E. Stevenson, R.A. Johnson, D.R. Greenwood, and R.P. Hellens. 2013. Phenotypic changes associated with RNA interference silencing of chalcone synthase in apple (Malus $\times$ domestica). Plant J. 74:398-410.

De Bondt, A., K. Eggermont, I. Penninckx, I. Goderis, and W.F. Broekaert. 1996. Agrobacteriummediated transformation of apple (Malus $\times$ domestica Borkh.): An assessment of factors affecting regeneration of transgenic plants. Plant Cell Rep. 15:549-554.

Duncan, D.B. 1955. Multiple range and multiple $F$ tests. Biometrics 11:1-42.

Ellul, P., B. Garcia-Sogo, B. Pineda, G. Ríos, L.A. Roig, and V. Moreno. 2003. The ploidy level of transgenic plants in Agrobacterium-mediated transformation of tomato cotyledons (Lycopersicon esculentum L. Mill.) is genotype and procedure dependent. Theor. Appl. Genet. 106:231-238.

Famiani, F., N. Ferradini, P. Staffolani, and A. Standardi. 1994. Effect of leaf excision time and age, BA concentration and dark treatments on in vitro shoot regeneration of M.26 apple rootstock. J. Hort. Sci. 69:679-685.

Fasolo, F., R.H. Zimmerman, and I. Fordham. 1989. Adventitious shoot formation on excised leaves of in vitro grown shoots of apple cultivars. Plant Cell Tissue Organ Cult. 16:75-87.

Flachowsky, H., I. Szankowski, S. Waidmann, A. Peil, C. Tränkner, and M.V. Hanke. 2012. The MdTFL1 gene of apple (Malus $\times$ domestica Borkh.) reduces vegetative growth and generation time. Tree Physiol. 32:1288-1301.

Gahan, P.B. and E.F. George. 2008. Adventitious regeneration, p. 355-401. In: E.F. George, M.A. Hall, and G.J. De Klerk (eds.). Plant propagation by tissue culture, 3rd ed. Springer, Dordrecht, Zuid-Holland.

Gentile, A., S. Monticelli, and C. Damiano. 2002. Adventitious shoot regeneration in peach [Prunus persica (L.) Batsch]. Plant Cell Rep. 20:10111016.

Holefors, A., Z.T. Xue, L.H. Zhu, and M. Welander. 2000. The Arabidopsis phytochrome B gene influences growth of the apple rootstock M26. Plant Cell Rep. 19:1049-1056.

James, D.J., A.J. Passey, and E. Rugini. 1988. Factors affecting high frequency plant regeneration from apple leaf tissues cultured in vitro. J. Plant Physiol. 132:148-154.

Lau, J.M. and S.S. Korban. 2010. Transgenic apple expressing an antigenic protein of the human respiratory syncytial virus. J. Plant Physiol. 167:920-927.

Leng, P.S., S.C. Su, F. Wei, F. Yu, and Y.F. Duan. 2009. Correlation between browning, total phenolic content, polyphenol oxidase and several antioxidation enzymes during pistachio tissue culture. Acta Hort. 829:127-132.

Liu, X.M. and P.M. Pijut. 2008. Plant regeneration from in vitro leaves of mature black cherry (Prunus serotina). Plant Cell Tissue Organ Cult. 94:113-123.

Magyar-Tábori, K., J. Dobránszki, J.A. Teixeira da Silva, S.M. Bulley, and I. Hudák. 2010. The role of cytokinins in shoot organogenesis in apple. Plant Cell Tissue Organ Cult. 101:251267.

Matsuda, N., M. Gao, K. Isuzugawa, T. Takashina, and K. Nishimura. 2005. Development of an Agrobacterium-mediated transformation method for pear (Pyrus communis L.) with leaf-section and axillary shoot-meristem explants. Plant Cell Rep. 24:45-51.

Metwali, E.M.R., H.I.A. Soliman, O.A. Almaghrabi, and N.M. Kaddasa. 2016. Producing transgenic thompson seedless grape (Vitis vinifera) plants using Agrobacterium tumefaciens. Intl. J. Agr. Biol. 18:661-670.

Modgil, M., D.R. Sharma, and S.V. Bhardwaj. 1999. Micropropagtion of apple cv. Tydeman's early worcester. Sci. Hort. 81:179-188.

Nakajima, I., Y. Sato, T. Saito, T. Moriguchi, and T. Yamamoto. 2013. Agrobacterium-mediated genetic transformation using cotyledons in Japanese pear (Pyrus pyrifolia). Breed. Sci. 63:275-283

Norelli, J.L., E. Borejsza-Wysocka, J.P. Reynoird, and H.S. Aldwinckle. 2000. Transgenic 'Royal Gala' apple expressing attacin E has increased field resistance to Erwinia amylovora (fire blight). Acta Hort. 538:631-633.

Pan, M.J. and J. van Staden. 1998. The use of charcoal in in vitro culture - A review. Plant Growth Regulat. 26:155-163.

Passey, A.J., K.J. Barrett, and D.J. James. 2003. Adventitious shoot regeneration from seven commercial strawberry cultivars (Fragaria $\times$ ananassa Duch.) using a range of explant types. Plant Cell Rep. 21:397-401.

Pawlicki, N. and M. Welander. 1994. Adventitious shoot regeneration from leaf segments of in vitro cultured shoots of the apple rootstock Jork 9. J. Hort. Sci. 69:687-696.

Qu, S.C., X.D. Huang, Z. Zhang, Q.H. Yao, J.M. Tao, Y.S. Qiao, and J.Y. Zhang. 2005. Agrobacterium-mediated transformation of Malus robusta with tomato iron transporter gene. J. Plant Physiol. Mol. Biol. 31:235-240.

Requesens, D.V., R.P. Malone, and P.J. Dix. 2014. Expression of a barley peroxidase in transgenic apple (Malus domestica L.) results in altered growth, xylem formation and tolerance to heat stress. J. Plant Sci. 9:58-66.

Saito, A. and M. Suzuki. 1999. Plant regeneration from meristem-derived callus protoplasts of apple (Malus $\times$ domestica cv. 'Fuji'). Plant Cell Rep. 18:549-553.

Soliman, H.I.A. 2013. In vitro regeneration and genetic transformation of peach (Prunus persica L.) plants. Life Sci. J. 10:487-496.

Sujatha, M., S. Vijay, S. Vasavi, P. Veera Reddy, and S. Chander Rao. 2012. Agrobacteriummediated transformation of cotyledons of mature seeds of multiple genotypes of sunflower (Helianthus annuus L.). Plant Cell Tissue Organ Cult. 110:275-287.

Sun, Q.R., H.Y. Sun, Q.Z. Liu, and Y.P. Shi. 2000 Regeneration of adventitious plants from leaves of different-ploidy apple trees. Deciduous Fruits 2:9-11.

Wang, N., T.L. Guo, X. Sun, X. Jia, P. Wang, Y. Shao, B. Liang, X.Q. Gong, and F.W. Ma. 2017. Functions of two Malus hupehensis (Pamp.) Rehd. YTPs (MhYTP1 and MhYTP2) in biotic- and abiotic-stress responses. Plant Sci. 261:18-27.

Wang, Q.C., H.R. Tang, Y. Quan, and Y.Q. Tang. 1994. Phenol induced browning and establishment of shoot-tip explants of 'Fuji' apple and 'Jinhua' pear cultured in vitro. J. Hort. Sci. 69:833-839.

Wang, S.H., M.Y. Yang, M. Gu, S.C. Qu, Q.H. Yao, and Z. Zhang. 2007. Agrobacteriummediated transformation of Malus micromalus with trivalent genes Rirol. J. Fruit Sci. 24:731736.

Welander, M. 1988. Plant regeneration from leaf and stem segments of shoots raised in vitro from mature apple trees. J. Plant Physiol. 132:738-744.

Zhang, Q., K.M. Folta, and T.M. Davis. 2014. Somatic embryogenesis, tetraploidy, and variant leaf morphology in transgenic diploid strawberry (Fragaria vesca subspecies vesca 'Hawaii 4'). BMC Plant Biol. 14:23.

Zhang, Z.H., S.X. Jing, G.L. Wang, H.J. Fang, and L.P. Wu. 1997. Genetic transformation of the commercial apple cultivar New Jonagold and regeneration of its transgenic plants. Acta Hort. Sin. 24:378-380.

Zhou, H.C., M. Li, X. Zhao, X.C. Fan, and A.G. Guo. 2010. Plant regeneration from in vitro leaves of the peach rootstock 'Nemaguard' (Prunus persica $\times P$. davidiana). Plant Cell Tissue Organ Cult. 101:79-87. 


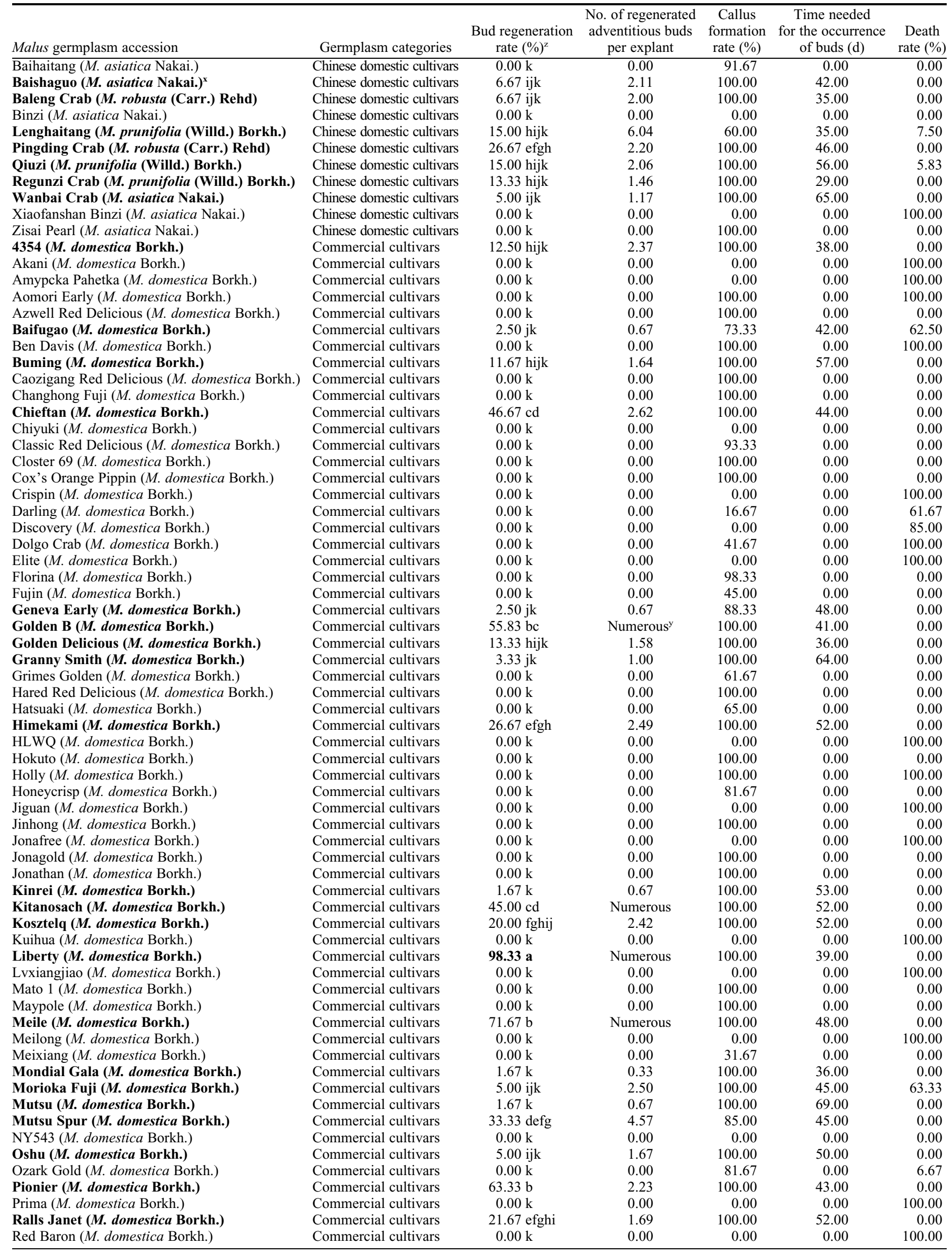




\begin{tabular}{|c|c|c|c|c|c|c|}
\hline Malus germplasm accession & Germplasm categories & $\begin{array}{l}\text { Bud regeneration } \\
\text { rate }(\%)^{z}\end{array}$ & $\begin{array}{l}\text { No. of regenerated } \\
\text { adventitious buds } \\
\text { per explant }\end{array}$ & $\begin{array}{l}\text { Callus } \\
\text { formation } \\
\text { rate }(\%)\end{array}$ & $\begin{array}{l}\text { Time needed } \\
\text { for the occurrence } \\
\text { of buds (d) }\end{array}$ & $\begin{array}{l}\text { Death } \\
\text { rate }(\%)\end{array}$ \\
\hline Red Rome (M. domestica Borkh.) & Commercial cultivars & $0.00 \mathrm{k}$ & 0.00 & 0.00 & 0.00 & 0.00 \\
\hline Red Sekaiichi (M. domestica Borkh.) & Commercial cultivars & $0.00 \mathrm{k}$ & 0.00 & 95.00 & 0.00 & 0.00 \\
\hline Royal Gala (M. domestica Borkh.) & Commercial cultivars & 38.33 de & 2.33 & 100.00 & 41.00 & 0.00 \\
\hline Ruby (M. domestica Borkh.) & Commercial cultivars & $0.00 \mathrm{k}$ & 0.00 & 21.67 & 0.00 & 65.00 \\
\hline Sanatore (M. domestica Borkh.) & Commercial cultivars & $0.00 \mathrm{k}$ & 0.00 & 100.00 & 0.00 & 0.00 \\
\hline Seimei (M. domestica Borkh.) & Commercial cultivars & $1.67 \mathrm{k}$ & 0.67 & 100.00 & 50.00 & 85.00 \\
\hline Sensu (M. domestica Borkh.) & Commercial cultivars & $0.00 \mathrm{k}$ & 0.00 & 91.67 & 0.00 & 100.00 \\
\hline Shengli (M. domestica Borkh.) & Commercial cultivars & $0.00 \mathrm{k}$ & 0.00 & 0.00 & 0.00 & 100.00 \\
\hline Shinsekai (M. domestica Borkh.) & Commercial cultivars & $0.00 \mathrm{k}$ & 0.00 & 0.00 & 0.00 & 100.00 \\
\hline Shizuka (M. domestica Borkh.) & Commercial cultivars & $0.00 \mathrm{k}$ & 0.00 & 100.00 & 0.00 & 0.00 \\
\hline Smoothee (M. domestica Borkh.) & Commercial cultivars & 93.33 a & Numerous & 100.00 & 32.00 & 0.00 \\
\hline Souland Crab (M. domestica Borkh.) & Commercial cultivars & $56.67 \mathrm{bc}$ & 1.75 & 100.00 & 33.00 & 0.00 \\
\hline Starkspur Red (M. domestica Borkh.) & Commercial cultivars & $0.00 \mathrm{k}$ & 0.00 & 75.00 & 0.00 & 0.00 \\
\hline Syuukou (M. domestica Borkh.) & Commercial cultivars & $0.00 \mathrm{k}$ & 0.00 & 100.00 & 0.00 & 0.00 \\
\hline Szampion (M. domestica Borkh.) & Commercial cultivars & $0.00 \mathrm{k}$ & 0.00 & 100.00 & 0.00 & 0.00 \\
\hline Takaaki (M. domestica Borkh.) & Commercial cultivars & 10.00 hijk & 1.22 & 100.00 & 61.00 & 0.00 \\
\hline Tehong fuji (M. domestica Borkh.) & Commercial cultivars & $0.00 \mathrm{k}$ & 0.00 & 100.00 & 0.00 & 0.00 \\
\hline Tianhuangkui (M. domestica Borkh.) & Commercial cultivars & $1.67 \mathrm{k}$ & 0.33 & 100.00 & 59.00 & 0.00 \\
\hline Tianwang 1 (M. domestica Borkh.) & Commercial cultivars & $0.00 \mathrm{k}$ & 0.00 & 100.00 & 0.00 & 0.00 \\
\hline Tompkin's King (M. domestica Borkh.) & Commercial cultivars & $1.67 \mathrm{k}$ & 1.00 & 100.00 & 52.00 & 0.00 \\
\hline $\begin{array}{l}\text { Vallee Spur Red Delicious } \\
\text { (M. domestica Borkh.) }\end{array}$ & Commercial cultivars & $1.67 \mathrm{k}$ & 0.67 & 100.00 & 44.00 & 0.00 \\
\hline Wenhong (M. domestica Borkh.) & Commercial cultivars & $3.33 \mathrm{jk}$ & 1.00 & 100.00 & 57.00 & 0.00 \\
\hline Wijcik (M. domestica Borkh.) & Commercial cultivars & $0.00 \mathrm{k}$ & 0.00 & 0.00 & 0.00 & 100.00 \\
\hline M. sieversii 23 (M. sieversii (Ledeb.) Roem.) & Malus sieversii accessions & $0.00 \mathrm{k}$ & 0.00 & 45.00 & 0.00 & 60.00 \\
\hline M. sieversii 24 (M. sieversii (Ledeb.) Roem.) & Malus sieversii accessions & $0.00 \mathrm{k}$ & 0.00 & 100.00 & 0.00 & 0.00 \\
\hline M. sieversii 28 (M. sieversii (Ledeb.) Roem.) & Malus sieversii accessions & $0.00 \mathrm{k}$ & 0.00 & 71.67 & 0.00 & 0.00 \\
\hline M. sieversii 31 (M. sieversii (Ledeb.) Roem.) & Malus sieversii accessions & 98.33 a & Numerous & 100.00 & 29.00 & 0.00 \\
\hline CG24 (M. pumila Mill.) & Rootstocks & $0.00 \mathrm{k}$ & 0.00 & 0.00 & 0.00 & 100.00 \\
\hline CG80 (M. pumila Mill.) & Rootstocks & $0.00 \mathrm{k}$ & 0.00 & 100.00 & 0.00 & 0.00 \\
\hline M. xiaojinensis Cheng et Jiang & Rootstocks & $5.00 \mathrm{ijk}$ & 1.33 & 100.00 & 43.00 & 0.00 \\
\hline GM256 (M. hybrid) & Rootstocks & $0.00 \mathrm{k}$ & 0.00 & 0.00 & 0.00 & 100.00 \\
\hline M7 (M. pumila Mill.) & Rootstocks & $0.00 \mathrm{k}$ & 0.00 & 100.00 & 0.00 & 0.00 \\
\hline M9 (M. pumila Mill.) & Rootstocks & $8.33 \mathrm{ijk}$ & 2.22 & 100.00 & 34.00 & 0.00 \\
\hline MM106 (M. pumila Mill.) & Rootstocks & $0.00 \mathrm{k}$ & 0.00 & 100.00 & 0.00 & 21.67 \\
\hline P16 (M. hybrid) & Rootstocks & $7.50 \mathrm{ijk}$ & 0.89 & 100.00 & 41.00 & 0.00 \\
\hline P22 (M. hybrid) & Rootstocks & $36.67 \mathrm{def}$ & 2.98 & 100.00 & 39.00 & 0.00 \\
\hline Zaai 76 (M. baccata (L.) Borkh.) & Rootstocks & $0.00 \mathrm{k}$ & 0.00 & 100.00 & 0.00 & 0.00 \\
\hline Banbishan Crab (M. prunifolia (Willd.) Borkh.) & Wild species & $0.00 \mathrm{k}$ & 0.00 & 100.00 & 0.00 & 0.00 \\
\hline Dage Crab (M. prunifolia (Willd.) Borkh.) & Wild species & $0.00 \mathrm{k}$ & 0.00 & 0.00 & 0.00 & 0.00 \\
\hline Gunzi (M. prunifolia (Willd.) Borkh.) & Wild species & 21.67 efghi & 1.79 & 97.50 & 42.00 & 0.00 \\
\hline Honghaitang 2 (M. asiatica Nakai.) & Wild species & $5.00 \mathrm{ijk}$ & 1.11 & 100.00 & 58.00 & 0.00 \\
\hline M. coronaria $(\mathrm{L}$.$) Mill.$ & Wild species & $0.00 \mathrm{k}$ & 0.00 & 100.00 & 0.00 & 0.00 \\
\hline M. halliana Koehne & Wild species & 17.50 ghijk & 1.63 & 100.00 & 54.00 & 0.00 \\
\hline M. ioensis (Wood.) Brit & Wild species & $0.00 \mathrm{k}$ & 0.00 & 100.00 & 0.00 & 100.00 \\
\hline M. mandshurica (Komarovii) Likh. & Wild species & $0.00 \mathrm{k}$ & 0.00 & 100.00 & 0.00 & 0.00 \\
\hline M. orbrophila Hand.-Mazz & Wild species & $0.00 \mathrm{k}$ & 0.00 & 0.00 & 0.00 & 0.00 \\
\hline M. orientalis Uglitzk. & Wild species & $0.00 \mathrm{k}$ & 0.00 & 0.00 & 0.00 & 0.00 \\
\hline M. platycarpa Rehd. & Wild species & $0.00 \mathrm{k}$ & 0.00 & 0.00 & 0.00 & 0.00 \\
\hline M. prunifolia Borkh. var. ringo Asami & Wild species & $0.00 \mathrm{k}$ & 0.00 & 95.00 & 0.00 & 0.00 \\
\hline M. rockii Schmeid & Wild species & $2.50 \mathrm{jk}$ & 1.33 & 85.83 & 55.00 & 22.50 \\
\hline
\end{tabular}




\begin{tabular}{|c|c|c|c|c|c|c|}
\hline Malus germplasm accession & Germplasm categories & $\begin{array}{l}\text { Bud regeneration } \\
\text { rate }(\%)^{z}\end{array}$ & $\begin{array}{l}\text { No. of regenerated } \\
\text { adventitious buds } \\
\text { per explant }\end{array}$ & $\begin{array}{l}\text { Callus } \\
\text { formation } \\
\text { rate }(\%)\end{array}$ & $\begin{array}{l}\text { Time needed } \\
\text { for the occurrence } \\
\text { of buds }(\mathrm{d})\end{array}$ & $\begin{array}{l}\text { Death } \\
\text { rate (\%) }\end{array}$ \\
\hline M. spectabilis (Ait.) Borkh. & Wild species & $6.67 \mathrm{ijk}$ & 0.78 & 100.00 & 57.00 & 0.00 \\
\hline M. sylvestris Mill. & Wild species & 21.67 efghi & 3.16 & 100.00 & 31.00 & 0.00 \\
\hline M. turkmenorum Juz. & Wild species & $0.00 \mathrm{k}$ & 0.00 & 0.00 & 0.00 & 0.00 \\
\hline M.baccata 2 (M. baccata (L.) Borkh.) & Wild species & $0.00 \mathrm{k}$ & 0.00 & 8.33 & 0.00 & 83.33 \\
\hline Qiuxing Crab (M. prunifolia (Willd.) Borkh.) & Wild species & $0.00 \mathrm{k}$ & 0.00 & 100.00 & 0.00 & 0.00 \\
\hline Sankuaishi Crab 1 (M. robusta (Carr.) Rehd) & Wild species & $44.17 \mathrm{~cd}$ & 2.27 & 100.00 & 34.00 & 0.00 \\
\hline Sankuaishi Crab 2 (M. robusta (Carr.) Rehd) & Wild species & $0.00 \mathrm{k}$ & 0.00 & 0.00 & 0.00 & 0.00 \\
\hline Weiai 3 (M. prunifolia (Willd.) Borkh.) & Wild species & $0.00 \mathrm{k}$ & 0.00 & 0.00 & 0.00 & 100.00 \\
\hline Weiai 4 (M. prunifolia (Willd.) Borkh.) & Wild species & $0.00 \mathrm{k}$ & 0.00 & 0.00 & 0.00 & 100.00 \\
\hline Wufengshan Crab 1 (M. hybrid) & Wild species & $56.67 \mathrm{bc}$ & 5.51 & 100.00 & 31.00 & 0.00 \\
\hline Wufengshan Crab 6 (M. hybrid) & Wild species & $26.67 \mathrm{efgh}$ & 2.63 & 96.67 & 44.00 & 6.67 \\
\hline Xiaomian Crab (M. prunifolia (Willd.) Borkh.) & Wild species & $0.00 \mathrm{k}$ & 0.00 & 0.00 & 0.00 & 0.00 \\
\hline
\end{tabular}

${ }^{\mathrm{z}} \mathrm{Bud}$ regeneration rates of the 153 Malus germplasm accessions were studied with Duncan's multiple-range test. The same letter within a column indicates no significant difference $(P<0.05)$.

${ }^{\mathrm{y}}$ For seven accessions, many adventitious buds were produced by the explants and could not be counted clearly. In these cases, "Numerous" was used in the "No. of regenerated buds per explant" column.

${ }^{\mathrm{x}}$ Sixty accessions with the nonzero regeneration rates, shown in bold, were used for the correlation analysis of different regeneration abilities.

Supplemental Table 2. F-test of regeneration abilities of the 10 Malus genetic resource accessions in different phenological stages.

\begin{tabular}{lcccc}
\hline & \multicolumn{2}{c}{$\mathrm{F}$ value } & & \\
\cline { 2 - 3 } Factor & $\mathrm{BRR}$ & $\mathrm{NAB}$ & $\mathrm{F}_{0.05}$ & $\mathrm{~F}_{0.01}$ \\
\hline Replicate & 0.81 & 2.65 & 3.11 & 4.88 \\
Genotype & $26.65^{* * *}$ & $24.57^{* *}$ & 2.00 & 2.64 \\
Phenologic stage & $25.10^{* *}$ & $30.54^{* *}$ & 3.11 & 4.88 \\
Genotype $\times$ Phenologic stage & $11.13^{* *}$ & $6.00^{* *}$ & 1.73 & 2.17 \\
\hline
\end{tabular}

$\mathrm{BRR}=$ bud regeneration rate; $\mathrm{NAB}=$ number of regenerated adventitious buds per explant.

** Significant at $P \leq 0.01$.

Supplemental Table 3. F-test of regeneration abilities of the 153 Malus germplasm accessions.

\begin{tabular}{lcccc}
\hline & \multicolumn{2}{c}{ F value } & & \\
\cline { 2 - 3 } Factor & $\mathrm{BRR}$ & $\mathrm{NAB}$ & $\mathrm{F}_{0.05}$ & $\mathrm{~F}_{0.01}$ \\
\hline Genotype & $42.63^{* *}$ & $42.95^{* *}$ & 1.21 & 1.31 \\
Replicate & 1.38 & 2.33 & 3.01 & 4.65 \\
\hline
\end{tabular}

$\mathrm{BRR}=$ bud regeneration rate; $\mathrm{NAB}=$ number of regenerated adventitious buds per explant.

**Significant at $P \leq 0.01$.

Supplemental Table 4. F-test of regeneration abilities of the 78 hybrids of Jonathan $x$ Golden Delicious.

\begin{tabular}{|c|c|c|c|c|}
\hline \multirow[b]{2}{*}{ Factor } & \multicolumn{2}{|c|}{ F value } & \multirow[b]{2}{*}{$\mathrm{F}_{0.05}$} & \multirow[b]{2}{*}{$\mathrm{F}_{0.0}$} \\
\hline & BRR & NAB & & \\
\hline Genotype & $11.63^{* *}$ & $11.98^{* * *}$ & 1.35 & 1.52 \\
\hline Replicate & 0.21 & 0.06 & 3.04 & 4.71 \\
\hline
\end{tabular}

$\mathrm{BRR}=$ bud regeneration rate; $\mathrm{NAB}=$ number of regenerated adventitious buds per explant.

**Significant at $P \leq 0.01$. 
Supplemental Table 5. Regeneration abilities of 78 hybrids of Jonathan $\times$ Golden Delicious.

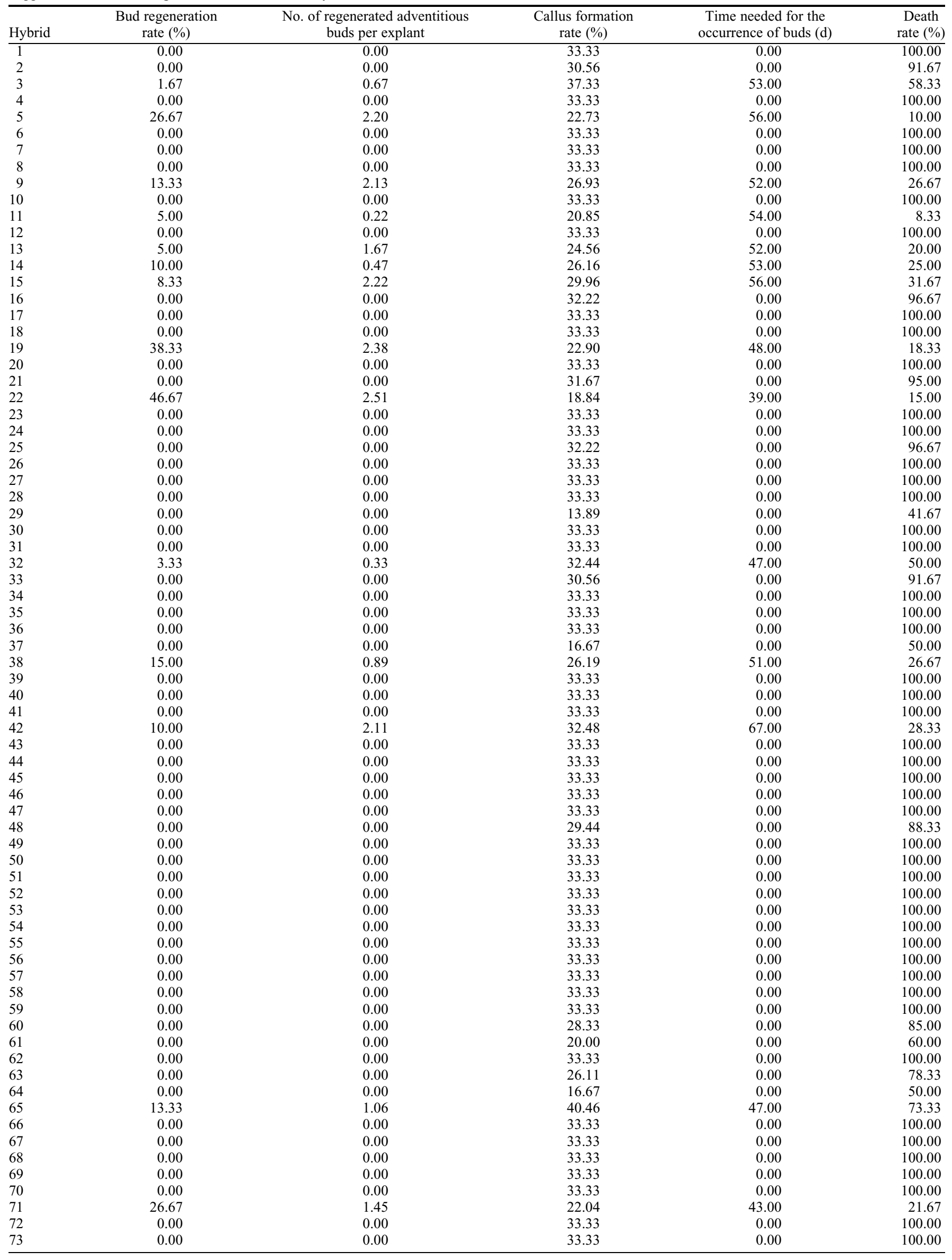


Supplemental Table 5. (Continued) Regeneration abilities of 78 hybrids of Jonathan $\times$ Golden Delicious.

\begin{tabular}{lcccr}
\hline Hybrid & $\begin{array}{c}\text { Bud regeneration } \\
\text { rate (\%) }\end{array}$ & $\begin{array}{c}\text { No. of regenerated adventitious } \\
\text { buds per explant }\end{array}$ & $\begin{array}{c}\text { Callus formation } \\
\text { rate (\%) }\end{array}$ & $\begin{array}{c}\text { Time needed for the } \\
\text { occurrence of buds (d) }\end{array}$ \\
\hline 74 & 0.00 & 0.00 & 33.33 & 0.00 \\
75 & 0.00 & 0.00 & 33.33 & 0.00 \\
76 & 0.00 & 0.00 & 33.33 & 0.00 \\
77 & 44.17 & 2.28 & 11.37 & 100.00 \\
78 & 0.00 & 0.00 & 33.33 & 26.00 \\
rate (\%)
\end{tabular}

